\title{
The link between HR practices, psychological contract fulfilment, and organisational performance in Greece:
} An economic crisis perspective

\author{
Anastasia A. Katou \\ University of Macedonia (Greece) \\ akatou@,uom.gr
}

Received: June 2012

Accepted: January 2013

\section{Abstrac:}

Purpose This study examines the impact of HR practices on organizational performance through the mediating role of psychological contract (expressed by the influence of employer on employee promises fulfilment through employee attitudes) and further examines whether this relationship remains stable during periods of external economic crisis.

Design/mathoddogy/approadr The analysis is based on structural equation modelling using two national samples of a two time study of Greek private and public organizations in the manufacturing, services and trade sectors. The first data collection took place in 2008 (treated as a control period) and the second in 2010 (treated as an economic crisis period).

Findings: The study is providing proof that the employee attitudes of satisfaction, commitment and motivation, constitute a nested mediating epicentre of the HR practices - organizational performance relationship, meaning that employee attitudes are positively influencing employee promises fulfilment and organizational performance and being positively influenced by employer promises fulfilment and HR practices. 
Research limitations/implications: Although data was collected using the same questionnaire at the two time periods of 2008 and 2010, the design of the study is not longitudinal. As a result, the study does not allow for dynamic causal inferences.

Originality/value The study supports the view that although the structure of the relationship between HR practices and organizational performance does not change in periods of economic crisis, the strength of this structure is weaker compared to normal economic periods. Additionally, this study provides a greater understanding of the process by which psychological contract mediates the relationship between HR practices and organizational performance, with special reference to economic crisis.

Keywords: HR practices, psychological contract, employee attitudes, organizational performance, economic crisis

\section{Introduction}

Although the relationships between human resource management (HRM) and organizational performance appear to be statistically weak, empirical research since the late 1990s demonstrates that 'HRM does matter' (Guest, Mitchie, Conway \& Sheeham, 2003; Wright, Gardner \& Moyniham, 2003). In trying to investigate the link between HRM and organizational performance several issues have been put forward (Paauwe \& Boselie, 2005). For example, the type and the number of variables or 'boxes' that mediate the relationship between HRM and organizational performance, that should be taken into account (Wright \& Gardner, 2003). Such intervening variables could be attitudinal outcomes (e.g., employee satisfaction, motivation, commitment) and behavioural outcomes (e.g., employee turnover, absence) which are closely linked to HRM. Institutional context is another issue that should also be taken into account when studying the HRM-performance relationship (Paauwe \& Boselie, 2003). This is because organizations are activated in wider institutional contexts (e.g., employment legislation, collective bargaining agreements, employee representation) that influence the employment relationship and the HRM decision making in organizations.

Multilevel analysis constitutes a major issue with respect to the empirical investigation when examining the sequence of the mediating variables in the HRM-performance relationship. For example, HRM practices may be analysed at employee group level, employee attitudes or behaviours may be looked at individual level, whilst performance may be measured at organizational level. To consider the problems raised by the multilevel analysis, the importance of blending research on the organizational level with research on the individual employee level has been emphasized (Wright \& Boswell, 2002). Typical organizational behaviour studies such 
as the psychological contract studies refer on the individual employee level, whilst typical strategic HRM studies refer on the group or organizational level. However, in blending these types of research appropriate aggregation of data should first be taken into account (Bliese, 2000).

Another important issue is how the HRM-performance relationship may be affected in cases of external shocks (Paauwe \& Boselie, 2005). An external shock may be a drastic change in the national economy. How this new economic situation may influence the relationship between HRM and organizational performance? For example, in times of national economic crisis organizations might change their HRM programmes by planning layoffs, recruit fewer employees, and make a range of cost-cutting changes such as restricting employee development expenditures and increasing employee contributions to health care premiums. How these changes, and other changes, in HRM may affect the feelings of employees? Usually in times of prosperity employees might feel more secure than in times of economic crisis. How these changes might affect employees' psychological contract? Finally, how any change due the external shock of the economic crisis will influence the HRM-performance relationship? Paauwe and Boselie (2005, p. 15) emphasizing that there is no "any study that explicitly takes into account these external events, but it might be possible that they affect the nature of the linkage between HRM and performance as well" suggest that "it would be interesting to study the relationship between HRM and performance in different economy cycles".

The purpose of this study is to investigate how the relationship between HRM and organizational performance will be affected by the recent financial and economic crisis in the context of Greece. Following a period of relative economic well-being through joining the euro area in 2001, Greece was subject to a range of pressures and difficulties in the period succeeding 2008, the year of the global financial and economic crisis. The general consequences of the financial and economic crisis in Greece may be summarised as following. The growth rate has decreased from $1.0 \%$ in 2008 to $-4.5 \%$ in 2010 , resulting in an increase of the unemployment rate from $7.7 \%$ to $12.6 \%$. Inflation has been increased from $4.0 \%$ in 2008 to $4.7 \%$ in 2010 . The fiscal deficit increased from $9.8 \%$ in 2008 to $10.5 \%$ in 2010 . The general government depth increased from $110.7 \%$ in 2008 to $142.8 \%$ in 2010 (European Economy, 2011). A Memorandum of Economic and Financial Policies between Greece and the euro area member states and IMF was agreed, that outlines the economic and financial policies that the Greek government will implement in the immediate coming period to strengthen market confidence and Greece's fiscal and financial position during a difficult transition period toward a more open and competitive economy.

For this purpose a model was proposed that investigates the impact of HR practices on organizational performance through the mediating role of psychological contract, expressed by the influence of employer on employee promises fulfilment, which takes into account the following issues. First, there is a lack of psychological contract research referring to employer 
and employee promises fulfilment (Grimmer \& Oddy, 2007; Nelson \& Tonks, 2007). Second, there is a lack of previous psychological contract research treating organizational performance as the ultimate dependent variable (de Jong, Schalk \& de Cuyper, 2009). Third, there is a scarcity of research considering that HR practices are antecedents of employer and employee promises fulfilment (Taylor \& Tekleab, 2004; Suazo, Martinez \& Sandoval, 2009), especially for non-Western contexts investigating the HR practices - psychological contract - organizational performance relationship (Pate, Martin \& McGoldrick, 2003). Fourth, although the concept of psychological contract originated from outside HRM literature, it is used in explaining how HR practices predict employee attitudes and behaviours within the psychological contract (Guest \& Conway, 2002; Cullinane \& Dundon, 2006; Seeck \& Parzefall, 2010).

For comparison reasons the study was divided into two phases. In the first phase, a survey took place in 2008, which was considered to be the basic reference period before the actual economic crisis. In the second phase, a survey took place in 2010, which was considered to be the experimental reference period expressing the period of the economic crisis. However, period two of this study was not clearly planned in advance given the uncertain nature of the credit crisis, but we developed it given the opportunity it offered to examine the key research themes as a response to it. We acknowledge that 'precision matching' between the two survey periods, in terms of organizations and respondents was not fully possible to achieve, and thus the alternative efficient method of 'frequency distribution matching' was used in order to investigate whether the two samples were matched on central characteristics such as the demographics of organizations and people (Frankfort-Nachmias \& Nachmias, 1996).

\section{Research model and hypotheses}

Figure 1 presents an operational model linking HR practices, psychological contract and organizational performance. The proposed operational model assumes that the state of the psychological contract mediates the relationship between HR practices and organizational performance. Specifically, the model is constituted by two related systems; the psychological contract system and the HR practices system. The first system refers to psychological contract that is expressed by the relationship between employer promises fulfilment (e.g., transactional, relational) and employee promises fulfilment (e.g., transactional, relational) mediated by employee attitudes (e.g., satisfaction, commitment, motivation). This system is based on the notions of reciprocity and social exchange, whereas if the employer upholds his side of the bargain, this will make employees satisfied, committed and motivated, and so they will reciprocate by upholding their side of the bargain (Coyle-Shapiro \& Kessler, 2003; Rousseau, 1995). The second system refers to the relationship between HR practices (e.g., resourcing, development, rewards, relations) and organizational performance (e.g., effectiveness, efficiency, development, innovation, quality). This system is based on the high performance HR practices concept, whereas HR practices influence organizational performance 
because of psychological contract fulfilment (Rousseau, 1995). In more detail, the two systems of the proposed model are explained bellow:

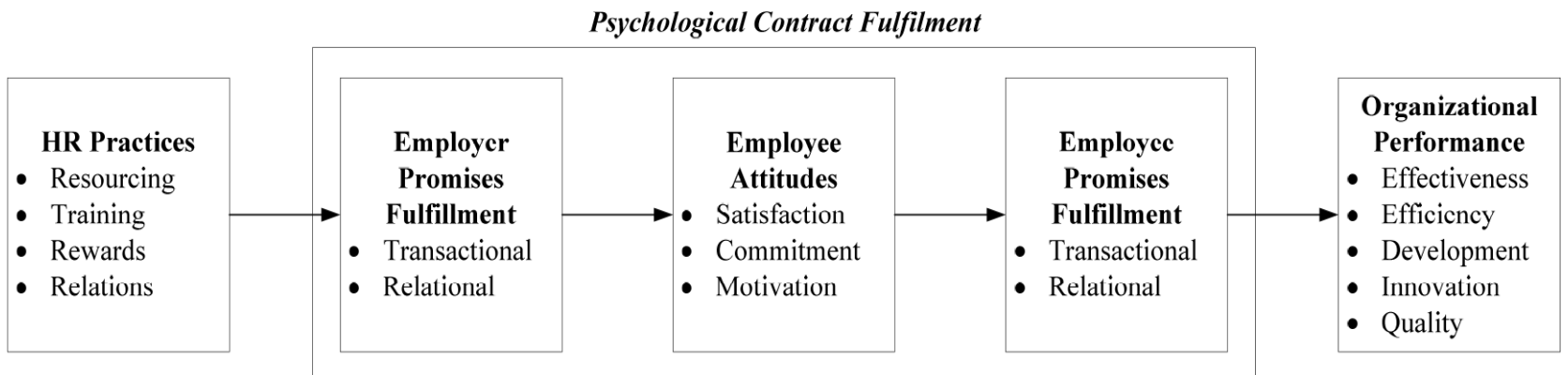

Figure 1. An HR practices - psychological contract - organizational performance linkage framework

\subsection{The psychological contract system}

Employees keep their promises according to the behaviour of the "good employer", or the "history" of the organization in keeping its promises to employees (Rousseau, 1995; Purcell \& Hutchinson, 2007). Specifically, in the context of the employment exchange relationship employees keep their promises if employers also keep their promises (Coyle-Shapiro, 2002; Coyle-Shapiro \& Kessler, 2003). "Reciprocity" constitutes a core component in the psychological contract, meaning that employees positively respond to favourable behaviour from their employers (Rousseau \& McLean Parks, 1993). In cases where employees believe that employers have broken their given promises, this will have a negative effect on employee promises fulfilment (Coyle-Shapiro \& Kessler, 2000).

In the proposed model employer and employee promises fulfilment are two related parts of psychological contracts. However, although psychological contracts are highly subjective (McDonald \& Makin, 2000), there are some common features that categorize psychological contracts into 'transactional' and 'relational' contracts (MacNeil, 1985; Rousseau, 1990). Transactional contracts involve short-term, specific, and monetary in nature beliefs such as competitive wage rates and performance-based pay. Relational contracts involve long-term, less specific, and monetary and non-monetary in nature beliefs such as job security, loyalty, training and development, career development, commitment and trust (Cavanaugh \& Noe, 1999; Robinson, Kraatz \& Rousseau, 1994; Rousseau, 1990).

Psychological contract literature, further, argues that fulfilment of the employer promises will be reciprocated by employee satisfaction, commitment and motivation (Coyle-Shapiro \& Kessler, 2000). For example, Robinson and Rousseau (1994) and Guest, Conway, Briner and Dickman (1996) support the view that employer contract influence job satisfaction and organizational commitment. Bies and Tripp (1995) argue that the state of the psychological contract in terms of fulfilment or breach will result to positive or negative employee attitudes respectively, which in turn will have an impact on employees in fulfilling their promises. CoyleShapiro and Kessler (2000), Robinson (1996), and Sturges, Conway, Guest, and Liefooghe 
(2005) support the view that employer promises fulfilment is positively related to employee commitment, supporting additionally that these attitudes will bring significant benefits to the organization in the form of increased efficiency. Generally, in cases where employees are satisfied, committed and motivated will keep their promises to the organization. Accordingly, we hypothesize that:

Hypothesis 1: Employee attitudes (e.g., satisfaction, commitment, motivation) mediate the relationship between employer promises fulfilment and employee promises fulfilment.

\subsection{The HR Practices system}

It is argued that HR practices, such as employee resourcing, development, rewards, and relations, influence psychological contracts by shaping employer and employee promises fulfilment (Suazo et al., 2009). Specifically, employee resourcing, being the beginning of the employment relationship, transmits the employment terms and conditions of the organization to the potential job applicants (Rynes, 1991). The emphasis the organization is putting on employee training and development usually reflects the view that the organization considers employees as being part of its permanent employment (Gomez-Mejia, Balkin \& Cardy, 2004). Each of the components of employee rewards is capable of producing psychological contract by establishing the belief that organization's employees worth their long-term salaries (GomezMejia et al., 2004). Good employee relations produce positive feelings to employees who accordingly keep their promises to organizations (Robinson et al., 1994). Consequently, HR practices are likely to influence psychological contracts. This is because the appropriate use of HR practices will create a positive organizational environment that will influence the degree of employer and employee promises fulfilment (Marchington, 2001; Purcell, Kinnie \& Hutchinson, 2003; Suazo et al., 2009). Thus, HR practices determine the status of psychological contracts by shaping the day-to-day behaviours of the members in an organization (Rousseau, 1995).

Consequently, a major function of HR practices is to cultivate a positive psychological contract that will lead to improved organizational performance (Pate et al., 2003; Suazo et al., 2009). This means that HR practices produce positive psychological contracts, reflected in the positive attitudinal reactions with respect to organizational commitment (Rousseau, 1990; Robinson \& Rousseau, 1994; Robinson et al., 1994; Lemire \& Rouillard, 2005), work satisfaction (Sutton \& Griffin, 2004), and motivation (Lester, Claire, \& Kickull, 2001), which consequently will improve organizational performance. Therefore, it has been argued that psychological contract mediates the relationship between HR practices and organizational performance (Tekleab, Lepak \& Bartol, 2001; Guest \& Conway, 2004). This means that better HR practices will produce superior psychological contracts, which by incorporating healthier employee attitudes will improve organizational performance (Seeck \& Parzefall, 2010). Therefore, we hypothesize that: 
Hypothesis 2: Psychological contract fulfilment mediates the relationship between HR practices and organizational performance.

\subsection{Issues of economic crisis}

During periods of economic crisis organisations usually layoff employees in order to be more cost efficient (Campbell, 1997; McKinley, Mone \& Barker, 1998). However, these layoffs create feelings of job insecurity among employees (DeWitt, 1998; Martin, Staines \& Pate, 1998). Therefore, the implicit social contract of job security for loyalty between employees and employers is usually broken (Lee, Phan \& Tan, 2003). As a result of possible layoffs employees are trying to develop new skills and update old ones in order to remain employable in the rapidly changing environment (Griffith, 1998). Training is one of the methods that employees use in order to develop new skills and update old ones, aiming at maintaining their current job security and improving their future employment prospects (Heyes \& Stuart, 1996). Additionally, training will help employees to be in command of their own careers in the internal labour market (Arthur \& Rousseau, 1996) and deal with employability in the external labour market in the event of a dismissal (Rousseau \& Arthur, 1999). However, we would expect employees to try to minimise their job insecurity, to be more flexible and to undergo more training and development in periods of economic crisis in comparison to the periods of economic recovery (Lee et al., 2003).

Performance appraisal is considered to be one of the major processes in the employment relationship because employees are aware that their work in the organisation will be evaluated and accordingly rewarded. However, if workers do not receive the expected rewards according to their good performance due to economic crisis, they will be de-motivated and furthermore, they will start doubting the purpose of performance appraisal (Davila \& Elvira, 2007). Thus, employees will be sceptical of employer promises referring to opportunities for promotion, good rewards and benefits, and other recognitions.

It has been argued that due to increased globalization, rapid technological development, and asymmetric economic instability, organisations frequently change their strategies aiming at restructuring their organisations in order to survive in the strongly intensified competitive environment. Lay-offs and redundancies, bringing a sense of insecurity in employees, are the usual side effects of these strategies (Westwood, Sparrow \& Leung, 2001). Economic liberalization and privatisation usually results in increased stress, declining job security and downsizing (Luo, 2002; Budhwar \& Debrah, 2009). Similarly, it has been argued that these changes alter the nature of psychological contracts, often leading to contract breaches and violations (Morrison \& Robinson, 1997), which are linked to a number of downward adjustments in employee attitudes and behaviours (Zhao, Wayne, Glibkowsky \& Bravo, 2007).

Summarising, it may be argued that in periods of economic crisis employees are trying to develop their employability in the external labour market in the event of a dismissal, be more flexible 
within the organization in order to be able to maximise their job security in the internal market, and be more sceptical of employer promises referring to opportunities for promotion, good rewards and benefits, and other recognitions. Furthermore, strategies aiming at restructuring organisations in order to survive in the strongly intensified competitive environment generally lead to psychological contract breaches and violations, and downsizing that increase stress and demotivation of employees. All these make much weaker the links in the employment relationship during periods of economic crisis. Accordingly, it is hypothesised that:

Hypothesis 3: The strength of the links in the employment relationship is weaker in periods of economic crisis.

\section{Method}

\subsection{Sample}

Data for this research was initially collected in April-May 2008 (i.e., two years before the economic crisis seriously affected Greece) by help of a questionnaire, which was administered with the employees of public and private firms in the manufacturing, services and trade sectors covering whole of Greece. The samplers were 120 individuals pursing management degrees at a Greek business school who helped to collect data from their organisations and also from their contact organisations. The survey instrument was distributed to 600 organisations with more than 20 employees. The questionnaires were filled face-to-face with the help of the samplers who followed a specific seminar for this purpose. Following Gerhart, Wright, McMahan and Snell (2000) who suggest that the reliability of structural measures will be increased by using 5-10 respondents per firm, the samplers were asked to concentrate on 6 respondents from each firm; two at management level (one from the HRM/Personnel Department and one from the Finance Department) and four at other employees' level, i.e. 3600 questionnaires altogether. 912 usable questionnaires were returned from the employees in 177 firms, a response rate of $29.5 \%$ at firm level, and $25.3 \%$ at employee level. Similarly, data was further collected in April-May 2010 (i.e., during the year of the economic crisis) by help of the same individuals attending the management degrees who helped with the questionnaire survey for the first phase. They were requested to approach the same 600 organizations which participated during the first phase and where possible same respondents to complete the surveys. This time, 897 usable questionnaires were returned from the employees in 156 firms, a response rate of $26.0 \%$ at firm level, and $24.9 \%$ at employee level.

The sample demographic characteristics with respect to organisations for both years are shown in Table 1. X-square homogeneity tests for each nominal characteristic (sector, ownership, size) and t-tests for each continuous characteristic (mean size) were used in order to investigate whether the samples for both years came from the same population. The exact significance levels of these tests are shown in the last column in Table 1. As all significance levels were 
higher than 0.05 we accept the hypothesis that the samples of the organisations for all characteristics came from the same population.

\begin{tabular}{|c|c|c|c|c|c|}
\hline \multirow[t]{2}{*}{ Period } & \multicolumn{2}{|c|}{2008} & \multicolumn{2}{|c|}{2010} & \multirow{2}{*}{$\begin{array}{l}\text { Tests and } \\
\text { significant } \\
\text { levels }\end{array}$} \\
\hline & Number & Percentage & Number & Percentage & \\
\hline Sample size & 177 & & 156 & & \\
\hline \multicolumn{6}{|l|}{ Sector } \\
\hline Manufacturing & 57 & 32.2 & 52 & 33.3 & $x^{2}-$ test \\
\hline Services & 78 & 44.1 & 68 & 43.6 & $p=0.974$ \\
\hline Trade & 42 & 23.7 & 36 & 23.1 & \\
\hline \multicolumn{6}{|l|}{ Ownership } \\
\hline Public & 45 & 25.4 & 40 & 25.6 & $x^{2}-$ test \\
\hline Private & 132 & 74.6 & 116 & 74.4 & $p=0.532$ \\
\hline \multicolumn{6}{|l|}{ Size } \\
\hline $20-100$ & 111 & 62.7 & 105 & 67.3 & $x^{2}-$ test \\
\hline $100-500$ & 45 & 25.4 & 43 & 27.6 & $p=0.770$ \\
\hline $500+$ & 21 & 11.9 & 8 & 5.1 & \\
\hline $\begin{array}{l}\text { Mean size } \\
\text { ( } \pm \text { standard error) }\end{array}$ & $\begin{array}{r}152.02 \\
( \pm 26.57)\end{array}$ & & $\begin{array}{r}168.48 \\
( \pm 16.74)\end{array}$ & & $p=0.347$ \\
\hline
\end{tabular}

Table 1. Sample demographics with respect to organisations

The sample demographic characteristics with respect to respondents for both years are shown in Table 2. As for Table 1, X-square homogeneity tests for each nominal characteristic (sector, ownership, size, sex, position, age, seniority) and t-tests for each continuous characteristic (mean size, mean age, mean seniority) were used in order to investigate whether the samples for both years came from the same population. The exact significance levels of these tests are shown in the last column in Table 2. As all significance levels were higher than 0.05 we accept the hypothesis that the samples of the respondents for all characteristics came from the same population.

Although 'precision matching' between the two survey periods was preferable, still, the efficient method of 'frequency distribution matching' indicated that the two samples were matched on central characteristics such as the demographics of organisations and people. Hence, it may be deduced that the samples for both organizations and respondents came from the same population for both years respectively. Therefore, any differences in the results reported in the rest of the paper may be attributed to external factors and not to factors representing the two samples. The deterioration of the Greek economy between 2008 and 2010 is considered to be one really marked external factor. Although it could be easily argued that there are other external factors that may influence organizations, these factors could also be easily considered to constitute the differences in the contexts between the normal 2008 and the crisis 2010 economic periods in Greece. 


\begin{tabular}{|c|c|c|c|c|c|}
\hline \multirow[t]{2}{*}{ Period } & \multicolumn{2}{|c|}{2008} & \multicolumn{2}{|c|}{2010} & \multirow{2}{*}{$\begin{array}{l}\text { Tests and } \\
\text { significant } \\
\text { levels }\end{array}$} \\
\hline & Number & Percentage & Number & Percentage & \\
\hline Sample size & 912 & & 897 & & \\
\hline \multicolumn{6}{|l|}{ Sector } \\
\hline Manufacturing & 348 & 38.2 & 325 & 36.2 & $x^{2}-$ test \\
\hline Services & 348 & 38.2 & 379 & 42.3 & $p=0.170$ \\
\hline Trade & 216 & 23.7 & 193 & 21.5 & \\
\hline \multicolumn{6}{|l|}{ Ownership } \\
\hline Public & 222 & 24.3 & 221 & 24.6 & $x^{2}-$ test \\
\hline Private & 690 & 75.7 & 676 & 75.4 & $p=0.600$ \\
\hline \multicolumn{6}{|l|}{ Size } \\
\hline $20-100$ & 537 & 58.9 & 532 & 59.3 & $x^{2}-$ test \\
\hline $101-500$ & 216 & 23.7 & 220 & 24.5 & $p=0.537$ \\
\hline $500+$ & 159 & 17.4 & 145 & 16.2 & \\
\hline $\begin{array}{l}\text { Mean size } \\
\text { ( } \pm \text { standard error) }\end{array}$ & $\begin{array}{r}170.20 \\
( \pm 11.00) \\
\end{array}$ & & $\begin{array}{r}185.54 \\
( \pm 7.69) \\
\end{array}$ & & $\begin{array}{r}\text { t-test } \\
p=0.208\end{array}$ \\
\hline \multicolumn{6}{|l|}{ Sex } \\
\hline Male & 492 & 53.9 & 494 & 55.1 & $x^{2}-$ test \\
\hline Female & 420 & 46.1 & 403 & 44.9 & $p=0.439$ \\
\hline \multicolumn{6}{|l|}{ Position } \\
\hline Manager & 252 & 27.6 & 227 & 25.3 & $x^{2}-$ test \\
\hline Worker & 660 & 72.4 & 670 & 74.7 & $p=0.442$ \\
\hline \multicolumn{6}{|l|}{ Age (in years) } \\
\hline-25 & 99 & 10.9 & 103 & 11.5 & $x^{2}-$ test \\
\hline $26-35$ & 300 & 32.9 & 290 & 32.3 & $p=0.980$ \\
\hline $36-45$ & 342 & 37.5 & 317 & 35.3 & \\
\hline $46+$ & 171 & 18.8 & 187 & 20.9 & \\
\hline $\begin{array}{l}\text { Mean age } \\
\text { ( } \pm \text { standard error) }\end{array}$ & $\begin{array}{r}37.54 \\
( \pm 0.30) \\
\end{array}$ & & $\begin{array}{r}36.89 \\
( \pm 0.32) \\
\end{array}$ & & $\begin{array}{r}t-\text { test } \\
p=0.133\end{array}$ \\
\hline \multicolumn{6}{|l|}{ Seniority (in years) } \\
\hline $1-5$ & 336 & 36.8 & 352 & 39.2 & $x^{2}-$ test \\
\hline $6-10$ & 237 & 26.0 & 217 & 24.2 & $p=0.946$ \\
\hline $11-15$ & 132 & 14.5 & 109 & 12.2 & \\
\hline $16+$ & 207 & 22.7 & 219 & 24.4 & \\
\hline $\begin{array}{l}\text { Mean seniority } \\
\text { ( } \pm \text { standard error) }\end{array}$ & $\begin{array}{r}10.04 \\
( \pm 0.26)\end{array}$ & & $\begin{array}{r}9.74 \\
( \pm 0.24)\end{array}$ & & $\begin{array}{r}\text { t-test } \\
p=0.278\end{array}$ \\
\hline
\end{tabular}

Table 2. Sample demographics with respect to respondents

\subsection{Measures}

\section{Organisational performance}

We used multiple organisational performance variables which were measured under the philosophy of a perceived rating of the organization's performance on a five-point scale ranging from 1 = 'very low' to 5 = 'very high'. The specific items constituting the organisational performance construct include: "effectiveness" - if the organisation meets its objectives; 
"efficiency" - if the organisation uses the fewest possible resources to meet its objectives; "development" - if the organisation is developing in its capacity to meet future opportunities and challenges; "innovation" - for products and processes; and "quality" - per cent of products of high quality, adopted from Delaney and Huselid (1996). Specifically, the respondents were asked "How would you rate 'effectiveness' [if the organisation meets its objectives] in your organization?"

\section{Employee attitudes}

Were measured with three aggregate items (e.g., satisfaction, commitment, motivation) following Katou (2008). We acknowledge that the employee satisfaction, commitment, and motivation items could instead be introduced as three distinctive constructs by themselves, and thus, they should not be combined into one general measure. However, we decided to accept this aggregation because our model was already too large and complex and by introducing into the model three more separate constructs would make it more complex without necessarily improving the validity of the model. Responses were made on a five-point scale ranging from 1 = 'very low' to 5 = 'very high'. Specifically, the respondents were asked "How would you rate 'satisfaction' in your organization?"

\section{Fulfilment of employer promises}

The construct of fulfilment of employer promises comprised of ten items, following the psychological contract CIPD (2008) fact sheet. Specifically, items that have been used in the past to reflect the transactional nature of employer promises in the psychological contract were pay commensurate with performance and an attractive benefits package, whilst items that have been used in the past to reflect the relational nature of employer promises in the psychological contract were opportunities for training and development, opportunities for promotion, recognition for innovation for new idea, feedback on performance, interesting tasks, respectful treatment, reasonable job security, a pleasant and safe working environment (McDonald \& Makin, 2000). Respondents were asked to indicate the degree to which they believed the employer has fulfilled its promises along a five-point scale from $1=$ 'not at all' to 5 = 'very well fulfilled' (Coyle-Shapiro \& Kessler, 2000). Specifically, the respondents were asked "How would you rate the fulfilment of the employer promises with respect to the 'opportunities for promotion' in your organization?"

\section{Fulfilment of employee promises}

The construct of fulfilment of employee promises comprised of ten items, following the psychological contract CIPD (2008) fact sheet. Specifically, items that have been used in the past to reflect the transactional nature of employee promises in the psychological contract were work hard, maintain high levels of attendance and punctuality, and work extra hours when required, whilst items that have been used in the past to reflect the relational nature of 
employee promises in the psychological contract were uphold company reputation, show loyalty to the organization, develop new skills and update old ones, be flexible, be courteous to clients and colleagues, be honest, come up with new ideas (Robinson et al., 1994). Respondents were asked to indicate the degree to which they believed the employee has fulfilled its promises along a five-point scale from $1=$ 'not at all' to $5=$ 'very well fulfilled' (Coyle-Shapiro \& Kessler, 2000). Specifically, the respondents were asked "How would you rate the fulfilment of the employee promises with respect to 'working hard' in your organization?"

\section{HR practices}

The construct of HR practices comprised of 12 items (e.g., recruitment, selection, flexible work arrangements; work design, performance appraisal, training and development; compensation, promotion, incentives; participation, involvement, communication) referring to the usual four key areas of resourcing, development, reward, and relations, developed by Armstrong (1996). The items were measured on a five-point scale ranging from $1=$ 'low use' to $5=$ 'high use'. Specifically, the respondents were asked "How would you rate the use of the 'training and development practice' in your organization?"

\section{Controls}

Several additional organisational and individual variables were controlled for in order to rule out alternative explanations of the findings (Turnley \& Feldman, 2000). Specifically, we used the controls of 'sector' $(' 1$ '=manufacturing, ' 2 '=services, ' 3 '=trade), 'ownership' $(' 1$ '=public, ${ }^{\prime} 2^{\prime}=$ private) and 'size' ('1'=20-100, ' 2 ' = $101-500,{ }^{\prime} 3^{\prime}=$ more than 500 , employees $)$.

\subsection{Consistency of the survey instrument}

Content validity of the questionnaire was established by operationalising well accepted and validated items developed in the literature (Straub, 1989). Construct internal consistency was investigated by evaluating the computed Cronbach (1951) alphas. The figures in Table 3 indicate that the survey instrument is reliable for testing the model presented in Figure 1 , as all Cronbach alphas are higher than 0.70 (Nunnally, 1978). Construct validity was examined by evaluating the percentage of the total variance explained per dimension obtained by applying confirmatory factor analysis (CFA) with varimax rotation and the eigenvalue greater than one criterion using LISREL (Jöreskog \& Sörbom, 2004). The percentage of total variance explained values are reported in Table 3, where all items loaded well on their respective factors (omitted for brevity), are higher than $50.0 \%$ indicating acceptable survey instrument construct validity (Hair, Anderson, Tatham, \& Black, 2008). Furthermore, construct validity was examined by evaluating the average variance extracted (AVE) per dimension obtained by applying CFA. The AVE values reported in Table 3 are much higher than 0.50 indicating acceptable survey instrument construct validity (Hair et al., 2008). Construct composite reliability was assessed by examining the calculated composite reliability scores (Pavlou \& Gefen, 2005). 


\begin{tabular}{|c|c|c|c|c|c|c|c|c|c|c|c|c|c|}
\hline Year & & 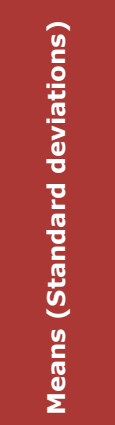 & 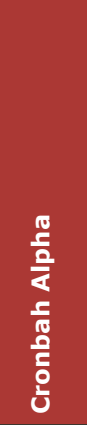 & 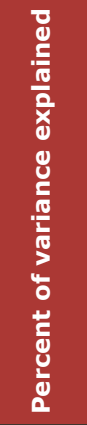 & 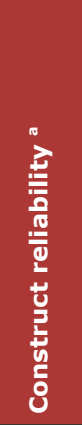 & 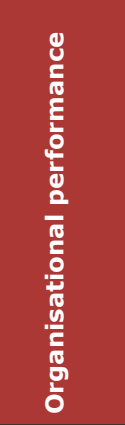 & 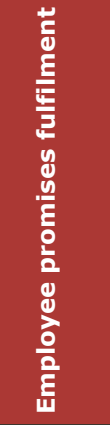 & $\begin{array}{l}\frac{y}{0} \\
\frac{\partial}{3} \\
\frac{3}{2}\end{array}$ & 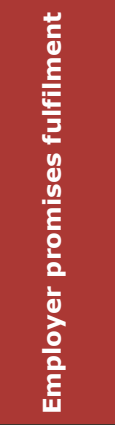 & $\begin{array}{l}\frac{y}{0} \\
\frac{0}{0} \\
\frac{0}{0} \\
\frac{0}{2} \\
\underline{x}\end{array}$ & 형 & $\begin{array}{l}\frac{0}{2} \\
\frac{1}{2} \\
\frac{5}{3} \\
0\end{array}$ & $\frac{N}{n}$ \\
\hline \multirow{8}{*}{2008} & $\begin{array}{l}\text { Organisational } \\
\text { performance }\end{array}$ & $\begin{array}{r}4.017 \\
(0.700)\end{array}$ & 0.875 & 71.81 & 0.963 & {$[0.714]^{b}$} & & & & & & & \\
\hline & $\begin{array}{l}\text { Employee } \\
\text { promises } \\
\text { fulfilment }\end{array}$ & $\begin{array}{r}3.831 \\
(0.574)\end{array}$ & 0.868 & 70.23 & 0.908 & $0.806^{* *}$ & [0.719] & & & & & & \\
\hline & Attitudes & $\begin{array}{r}3.616 \\
(0.733)\end{array}$ & 0.908 & 92.32 & 0.978 & $0.772^{* *}$ & $0.753^{* *}$ & [0.922] & & & & & \\
\hline & $\begin{array}{l}\text { Employer } \\
\text { promises } \\
\text { fulfilment }\end{array}$ & $\begin{array}{r}3.474 \\
(0.729)\end{array}$ & 0.938 & 72.26 & 0.962 & $0.838^{* *}$ & $0.724^{* *}$ & $0.832^{* *}$ & [0.717] & & & & \\
\hline & HR practices & $\begin{array}{r}3.350 \\
(0.702)\end{array}$ & 0.928 & 71.75 & 0.951 & $0.673^{* *}$ & $0.643^{* *}$ & $0.724^{* *}$ & $0.791^{* *}$ & {$[0.721]$} & & & \\
\hline & Sector & & & & & 0.063 & 0.082 & $0.169^{*}$ & $0.181^{*}$ & $0.171^{*}$ & 1 & & \\
\hline & Ownership & & & & & $0.489^{* *}$ & $0.322^{* *}$ & $0.332^{* *}$ & $0.376^{* *}$ & $0.250^{* *}$ & 0.143 & 1 & \\
\hline & Size & & & & & $-0.278^{* *}$ & $-0.190^{*}$ & $-0.335^{* *}$ & $-0.296^{* *}$ & -0.107 & -0.077 & $-0.264^{* *}$ & 1 \\
\hline \multirow{8}{*}{2010} & $\begin{array}{l}\text { Organisational } \\
\text { performance }\end{array}$ & $\begin{array}{r}3.950 \\
(0.621)\end{array}$ & 0.765 & 66.23 & 0.858 & {$[0.647]$} & & & & & & & \\
\hline & $\begin{array}{l}\text { Employee } \\
\text { promises } \\
\text { fulfilment }\end{array}$ & $\begin{array}{r}3.760 \\
(0.518)\end{array}$ & 0.805 & 56.79 & 0.865 & $0.635^{* *}$ & {$[0.472]$} & & & & & & \\
\hline & Attitudes & $\begin{array}{r}3.532 \\
(0.666)\end{array}$ & 0.748 & 82.80 & 0.881 & $0.646^{* *}$ & $0.597^{* *}$ & [0.811] & & & & & \\
\hline & $\begin{array}{l}\text { Employer } \\
\text { promises } \\
\text { fulfilment }\end{array}$ & $\begin{array}{r}3.4018 \\
(0.610)\end{array}$ & 0.874 & 64.71 & 0.918 & $0.653^{* *}$ & $0.526^{* *}$ & $0.662^{* *}$ & [0.625] & & & & \\
\hline & HR practices & $\begin{array}{r}3.469 \\
(0.613)\end{array}$ & 0.840 & 52.15 & 0.879 & $0.495^{* *}$ & $0.455^{* *}$ & $0.560^{* *}$ & $0.654^{* *}$ & [0.502] & & & \\
\hline & Sector & & & & & -0.004 & 0.026 & 0.106 & $0.162^{*}$ & 0.101 & 1 & & \\
\hline & Ownership & & & & & $0.474^{* *}$ & $0.329^{* *}$ & $0.298^{* *}$ & $0.372^{* *}$ & $0.269^{* *}$ & 0.116 & 1 & \\
\hline & Size & & & & & $-0.182^{*}$ & $-0.166^{*}$ & $-0.270^{* *}$ & $-0.220^{* *}$ & -0.117 & -0.059 & -0.123 & 1 \\
\hline
\end{tabular}

$* \mathrm{p}<0.05, * * \mathrm{p}<0.01$

a Construct reliability $=\left(\sum_{i} \lambda_{i}\right)^{2} /\left[\left(\sum_{i} \lambda_{i}\right)^{2}+\sum_{i}\left(1-\lambda_{i}^{2}\right)\right]$ where $\lambda_{i}=$ standardized loading

b Diagonal figures in brackets represent average variance extracted (AVE)

Table 3. Correlation coefficients

The figures in Table 3 indicate that the degree of construct composite reliability is acceptable for 2008, since all reliability scores exceed 0.90 , and the degree of construct composite reliability is rather acceptable for 2010 , since the reliability scores either exceed $\mathbf{0 . 9 0}$, or they are marginally lower than 0.90 . Construct discriminant validity was assessed by examining whether the correlation coefficients between pairs of constructs were significantly different 
from unity and by examining whether the square root of each factor's AVE is larger than its correlations with other factors. Table 3 presents the correlation coefficients of all constructs used in the study. It is seen that the correlation coefficients are significantly different from unity, and they are smaller than the square root of each factor's AVE, providing thus evidence for separate constructs.

To reduce the common method bias threat in the survey design, we asked multiple respondents from each organization to answer the questions of the questionnaire. However, taking into consideration that some correlation coefficients were rather high, Harman's (1967) single factor test was used to examine the likelihood of common method bias threat. According to this test the simultaneous loading of all items in a factor analysis, revealed seven factors, and not just one, with the first factor covering only $18.446 \%$ of total variance explained, for year 2008, and revealed nine factors, with the first factor covering only $29.913 \%$ of total variance explained, for year 2010, indicating thus that the common method bias in the data was rather limited.

\subsection{Statistical analysis}

To test the raised research questions of the proposed framework the methodology of 'structural equation models' (SEM) or 'latent variable models' (Hair et al., 2008) was used, via LISREL and the maximum likelihood estimation (MLE) (Jöreskog \& Sörbom, 2004). SEM is effective when testing models that are path analytic with mediating variables, and include latent constructs that are being measured with multiple items (Luna-Arocas \& Camps, 2008). We used MLE because tests of departure from normality, skewness and kurtosis for all variables used were (except for controls) within acceptable statistical limits. However, to avoid nested effects and problems due to the blending research on the organizational level with research on the individual employee level, we aggregated the data to mean scores at the organizational level. This is for two reasons. First, although data stem from different organizations potential biasing effects of organizational membership may be present. Second, psychological contracts are based on the perceptions and beliefs of individuals (McDonald \& Makin, 2000) although performance is based on the organizational level. Thus, to avoid any bias due to the non-independence in the data and to make analyses on relationships between individual data and performance data possible, individual scores on the survey were aggregated to mean scores at organizational level.

We assessed the overall model fit following Bollen's (1989) recommendation to examine multiple indices, since it is possible for a model to be adequate on one fit index but inadequate on many others. We used the chi-square test (with critical significant level $p>0.05$ ) and the normed-chi-square ratio (with critical level no more than 3 ), the goodness of fit index, GFI (with critical level not lower than 0.80), the normed fit index, NFI (with critical level not lower than 0.90), the comparative fit index, CFI (with critical level not lower than 0.90), and the root 
mean squared error of approximation, RMSEA (with critical level not more than 0.08) (Bentler, 1990).

\section{Results}

Table 3 presents the means and the standard deviations of all the constructs used in the study, for both survey periods, derived as weighed averages of confirmatory factor analyses applied to each group of relevant items. Furthermore, Table 3 displays the bivariate correlation coefficients between all constructs used in the study. We observe strong, positive and significant correlations between HR practices, organizational performance, employee attitudes, and employer and employee promises fulfilment, supporting the hypotheses of the study. With respect to organizational controls we see in Table 3 that generally there is a variety of correlations between controls and the rest of the variables used in the study.

However, results based on correlations, although interesting, may be misleading due to the interactions between several variables. Therefore, in order to isolate the possible links between the variables involved in the operational model presented in Figure 1, the estimated path diagrams for this proposed framework are presented in Figure 2 for 2008 and in Figure 3 for 2010. The circles represent the related latent variables and the bold arrows indicate the structural relationships between the corresponding variables. The numbers that are assigned to each arrow show the estimated standardized coefficients. All coefficients are significant at the 0.001 level.

The excellent goodness-of-fit indexes in Figure 2 confirmed the validity of the operational model $\quad$ (Chi-Square $=960.11, \quad \mathrm{df}=854, \quad \mathrm{p}$-value $=0.007, \quad$ Normed-Chi-Square $=1.12$, RMSEA $=0.027, \mathrm{NFI}=0.94, \mathrm{CFI}=1.00, \mathrm{GFI}=0.80)$. However, it must be noted here that the chi-square being significant indicates that the proposed model is not an adequate presentation of the entire set of relationships. But, taking into account that chi-square statistics may be inflated by high sample sizes, the value of the normed-chi-square (i.e., value of chi-square / degrees of freedom) was used instead. In our case this value is less than 3 , confirming the validity of our model (Pedhazur \& Pedhazur-Schelkin, 1991).

Considering that all the standardized coefficients are significant and the fit statistics of the model are acceptable we conclude that hypotheses $\mathrm{H} 1$ and $\mathrm{H} 2$ of the study are supported. This means that employee attitudes mediate the relationship between employer and employee promises fulfilment, and psychological contract fulfilment mediates the relationship between HR practices and organizational performance. However, as post hoc analysis, we re-estimated the same model adding two more links. A direct link from HR practices to organizational performance, and a direct link from employer to employee promises fulfilment. In this reestimation these two additional paths were not significant, indicating that the more parsimonious model was preferable. This result confirmed the support of hypotheses $\mathrm{H} 1$ and 
$\mathrm{H} 2$, reflecting full mediation of the psychological contract fulfilment in the HR practices organizational performance relationship.

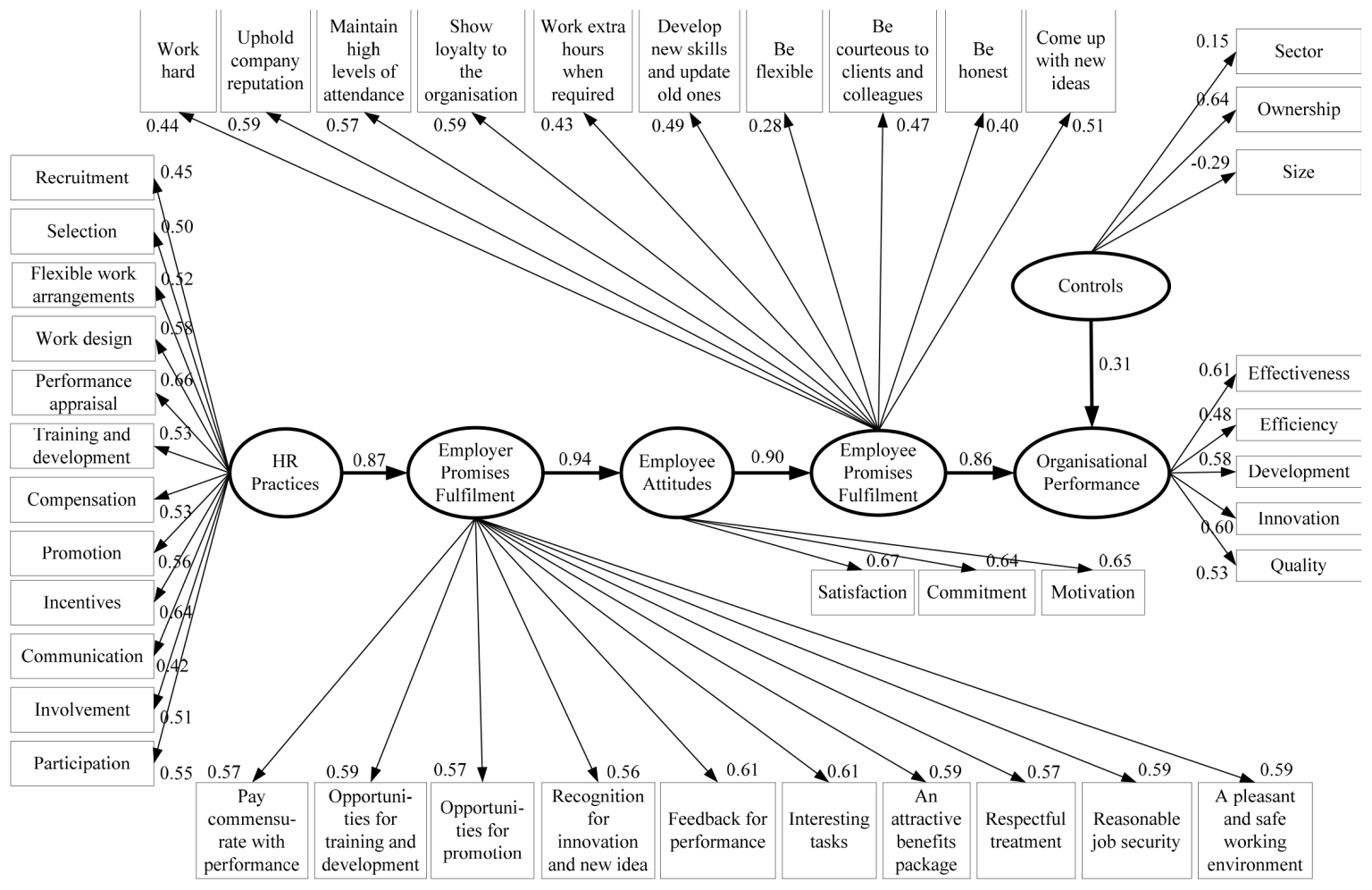

Chi-Square $=960.11 \mathrm{df}=854 \mathrm{p}$-value $=0.007$ Normed Chi-Square $=1.12$ RMSEA $=0.027$ NFI $=0.94$ CFI $=1.00 \quad$ GFI $=0.80$

Figure 2. Estimation results of the hypothesized model for year 2008

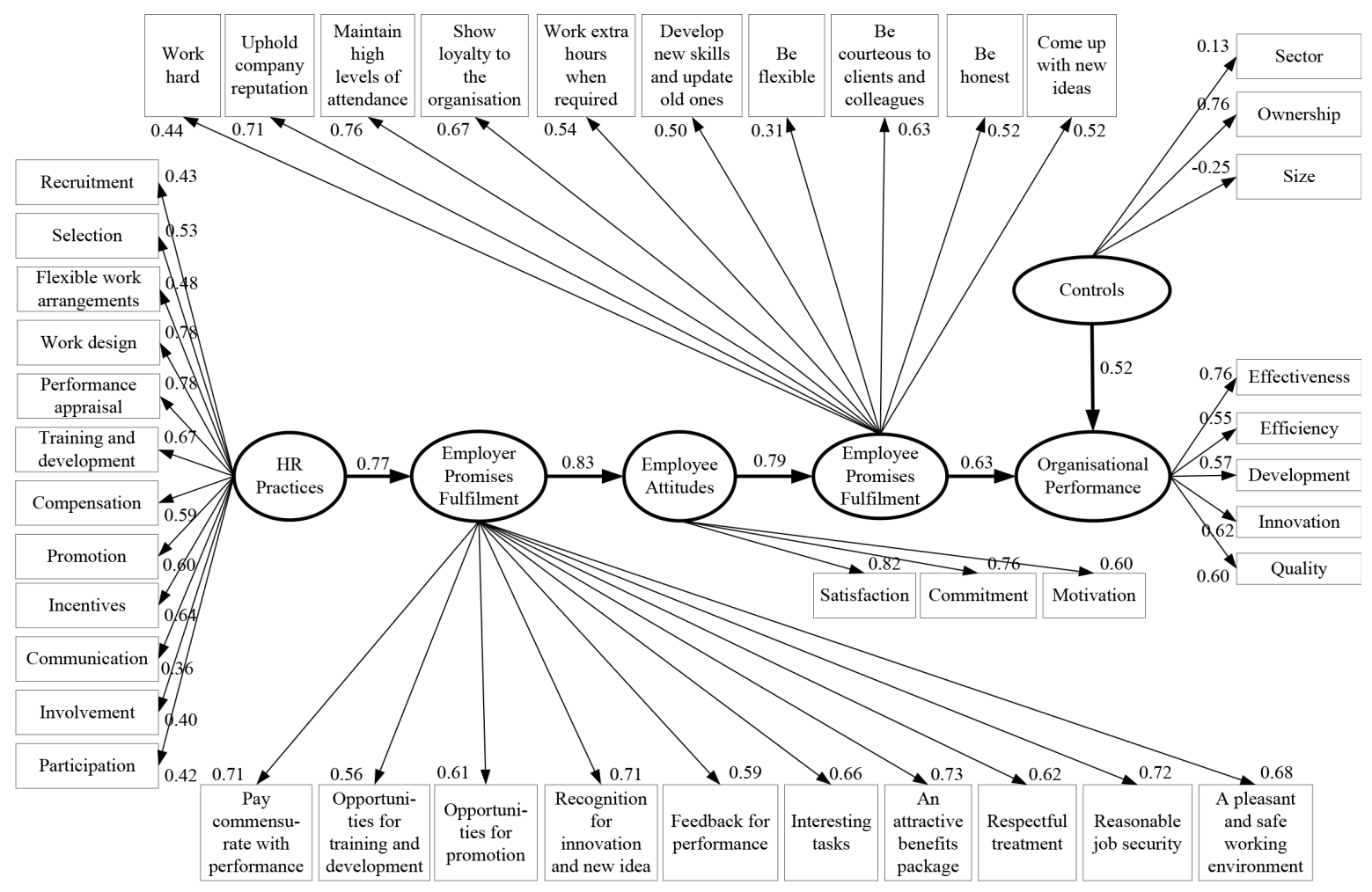

Chi-Square $=1296.92 \mathrm{df}=854 \mathrm{p}$-value $=0.000$ Normed Chi-Square $=1.52$ RMSEA $=0.078 \quad \mathrm{NFI}=0.91 \mathrm{CFI}=0.91 \quad \mathrm{GFI}=0.58$

Figure 3. Estimation results of the hypothesized model for year 2010 
Figure 3 shows the results of estimating the operational model presented in Figure 1, under the survey data of 2010. The rather acceptable goodness-of-fit indexes in Figure 3 confirmed the validity of the operational model (Chi-Square $=1296.92, \mathrm{df}=854, \mathrm{p}$-value $=0.000$, Normed-Chi-Square $=1.52, \mathrm{RMSEA}=0.078, \mathrm{NFI}=0.91, \mathrm{CFI}=0.91, \mathrm{GFI}=0.58$ ).

Undertaking the same post-hoc analysis as before we confirmed the support of hypotheses $\mathrm{H} 1$ and $\mathrm{H} 2$, reflecting also in this case the full mediation of the psychological contract fulfilment in the HR practices - organizational performance relationship.

Comparing the results in Figure 2 and 3 we see that in both periods, i.e. the normal period and the economic crisis period, the structure of the model is exactly the same. This means that under both periods the relationship between HR practices and organizational performance is mediated by psychological contract fulfilment, which is shaping the attitudes of the employees that accordingly influence organizational performance. However, the standardized coefficients of the links in Figure 3 are all smaller than the standardized coefficients of the corresponding links in Figure 2. This means that Hypothesis 3 is supported, indicating that the strength of the links in the employment relationship are weaker in periods of economic crisis.

Special reference should be made with respect to the controls used in estimation. Although we acknowledge that there is no a sound theoretical rationale to consider 'organizational controls as a distinct 'factor', we still use this factor for estimation purposes only in order to isolate the impact of the independent variables on organizational performance (Boselie, Dietz \& Boon, 2005). Additionally, we must note here that although we tried all possibilities connecting controls with all the other constructs (Paawe \& Richardson, 1997), the only significant results obtained are those reported in Figures 2 and 3 . Specifically, for both periods, the positive factor loadings of the sector item reveal that organizational performance is larger in the trade and services sectors than in the manufacturing sector. The positive factor loadings of the ownership item reveal that organizational performance in private organizations is higher than in public organizations in Greece. In contrast, the negative factor loadings of the size item reveal that organizational performance does not follow the economies of scale rule, as it usually hypothesized (Tzafrir, 2005).

\section{Discussion}

\subsection{Implications for theory}

The theoretical significance of this study is four-fold. First, this study confirms and extends existing empirical evidence concerning the basis of the HR practices - psychological contract organizational performance relationship. This is because a major finding of this relationship is that employee attitudes such as employee satisfaction, commitment and motivation, constitute the heart (Boxall \& Purcell, 2002) or the epicentre of this relationship. All other relationships are activated around this epicentre, meaning that employee attitudes are influencing employee 
promises fulfilment and organizational performance and being influenced by employer promises fulfilment and HR practices. Additionally, comparing the average of the standardized coefficients of the items constituting employee resourcing, training and development, rewards, and relations in the initial driving construct in Figures 2 and 3, it is seen that training and development is perceived by employees to be the most important group of HR practices that will help their employability both in the internal and external labour market (Arthur \& Rousseau, 1996; Lee et al., 2003). These findings not only support the theory that HR practices have a positive impact on organizational performance, on both normal and crisis economic periods, but also extend the literature referring to the HRM-performance relationship in a non US/UK context such as that of Greece.

Second, the study provides evidence of the reciprocal influence that occurs in the exchange relationship between employers and employees. This is because, for period 2008, in view of the standardized coefficients of the items constituting the employer promises fulfilment construct in Figure 2, it is seen that employer promises fulfilment with respect to feedback for performance and interesting tasks have the highest influence on employee satisfaction, motivation and commitment. These attitudes will make employees to positively react by keeping their promises with respect to upholding company reputation and showing loyalty to the organization. For period 2010, it is seen in Figure 3 that an attractive benefits package and reasonable job security are the employer promises that generally must be fulfilled for employees to maintain high levels of attendance and show loyalty to the organization. These results are important because they support the view that in periods of economic crisis employees are afraid that may lose their jobs and thus they show their best face to the organization by maintaining high levels of attendance.

Third, the study confirms and extends Rousseau's (1995) argument on the centrality of reciprocity with respect to how exchange relationships are governed (Coyle-Shapiro \& Kessler, 2003). This is because the major property of the conceptual model of the study is that the relationship between HR practices and organizational performance is mediated by psychological contract fulfilment, and employee attitudes are nested in this psychological contract. Although extensive empirical research has been carried out linking HR practices with organizational performance through employee attitudes, still little justification has been presented for how HR practices influence individual attitudes (Allen, Shore \& Griffeth, 2003). This study considers that the history of the organization in terms of keeping its promises to employees, being contingent on the HR practices employed, shapes both employee attitudes and the degree of employee promises fulfilment to the organization (see also Rousseau, 1995). This finding may give some light to the so-called "black-box" referring to the mechanism that exists between HR practices and organizational performance (Hutchison \& Purcell, 2003; Purcell et al., 2003). Moreover, this study supports the view that although the structure of the HR practices psychological contract fulfilment - organizational performance relationship does not change in 
periods of economic crisis, the strength of this structure is weaker compared to normal economic periods.

Fourth, this study provides evidence with respect to the relative importance of transactional vs. relational contracts when the external factor of economic crisis shocks the environment. The average values of the standardized coefficients reported in Figure 2 are equal to 0.58 for transactional and 0.59 for relational employer promises fulfilment, and to 0.48 for both transactional and relational employee promises fulfilment. These values indicate that during normal economic periods and for both parties, i.e. employers and employees, the transactional short-term promises fulfilment is perceived to have the same importance to the relational longterm promises fulfilment. On the contrary, the average values of the standardized coefficients reported in Figure 3 are equal to 0.72 for transactional and 0.64 for relational employer promises fulfilment, and to 0.58 for transactional and 0.55 for relational employee promises fulfilment. These values indicate that during crisis economic periods and for both parties, the transactional short-term promises fulfilment is perceived to have more importance to the relational long-term promises fulfilment. In other words, in terms of normal economic periods the organization puts the same emphasis in the transactional and the relational part of the contract, whilst during crisis economic periods the organization is more interested in the shortterm transactional contracts to cover its current needs. Therefore, our findings support the view that transactional aspects of the psychological contract must be fulfilled before relational aspects can be addressed (Millward \& Brewerton, 1999), because transactional aspects drive relational aspects due to their cause and effect association (Pate et al., 2003).

\subsection{Implications for practice / management}

The study has clear implications for both managers and decision makers in Greek organizations. It identifies employee training and development and rewards as the major HR practices potentially capable of sending signals that may lead to the creation of psychological contract fulfilment in both normal and crisis economic periods. Although it may be difficult to know exactly what constitutes the psychological contract of an employee (Suazo et al., 2009), in periods of economic crisis managers primarily must send messages of reasonable security to employees in order for them to largely keep their own promises about maintaining high levels of attendance and upholding company reputation. Finally, managers need to develop skills that will allow them to improve the employee attitudes of satisfaction, commitment, and motivation, because these attitudes constitute the nested epicentre mediating construct in both the HR practices - performance and employer - employee promises fulfilment relationships, which will improve organizational performance, in both normal and crisis economic periods. 


\subsection{Limitations}

This study has some limitations. First, considering that the second survey period was not clearly planned in advance, precision matching between the two survey periods, in terms of organizations and respondents, has not fully been achieved. This could possibly make the results to depend on other factors than the external shock of economic crisis. Second, although data was collected using the same questionnaire at the two time periods of 2008 and 2010, the design of the study is not longitudinal. As a result, the study does not allow for dynamic causal inferences (Cavanaugh \& Noe, 1999). Third, to minimize possible common method bias concerns data should be gathered from independent sources (Podsakoff \& Organ, 1986). Fourth, the study was applied in the context of Greece which has unique labour relations and institutional conditions, and thus the findings from the Greek sample may not generalize across borders (de Jong et al., 2009). However, despite these limitations, this study provides a greater understanding of the process by which psychological contract mediates the relationship between HR practices and organizational performance, with special reference to economic crisis.

\section{Conclusion}

Past research has provided extensive evidence on the positive relationship between HR practices and organizational performance in an effort to reveal a positive impact of $H R$ practices (Wright, Gardner, Moynihan \& Allen, 2005). This study is partially in line with Purcell et al. (2003) high performance model, where employee attitudes mediate the relationship between HR practices and organizational performance, and with Guest and Conway's (2004) psychological contract model where HR practices have a major influence on the state of the psychological contract, indicating that a positive psychological contract will lead to improved organizational performance. Thus, this study is attempting at providing proof that the employee attitudes of satisfaction, commitment and motivation, constitute the epicentre of the HRM - performance relationship. All other relationships are activated around this epicentre, meaning that employee attitudes are influencing employee promises fulfilment and organizational performance and being influenced by employer promises fulfilment and HR practices. Finally, this study supports the view that although the structure of this relationship does not change in periods of economic crisis, the strength of this structure is weaker compared with normal economic periods.

\section{References}

Allen, D.G., Shore, L.M., \& Griffeth, R.W. (2003). The role of perceived organizational support and supportive human resource practices in the turnover process. Journal of Management, 29, 99-118. http://dx.doi.org/10.1177/014920630302900107

Armstrong, M. (1996). A handbook of personnel management practice. London: Kogan Page. 
Arthur, M.B., \& Rousseau, D.M. (1996). The boundary less career: A new employment principle for a new organizational era. New York: Oxford University Press.

Bentler, P.M. (1990). Comparative fit indexes in structural models. Psychological Bulletin, 107, 238-246. http://dx.doi.org/10.1037/0033-2909.107.2.238

Bies, R.J., \& Tripp, T.M. (1995). Beyond distrust: "getting even" and the need for revenue. In Kramer, R.M. and Tyler, T. (eds.). Trust in organizations. Newbury Park, CA: Sage.

Bliese, P.D. (2000). Within-group agreement, non-independence, and reliability: implications for data aggregation and analysis. In Kleinand, K.J. and Kozlowski, S. (eds.). Multilevel theory, research, and methods in organizations. San Francisco: Jossey-Bass.

Bollen, K.A. (1989). Structural equations with latent variables. New York: Wiley.

Boselie, P., Dietz, G., \& Boon, C. (2005). Commonalities and contradictions in HRM and performance research. Human Resource Management Journal, 15, 67-94. http://dx.doi.org/10.1111/j.1748-8583.2005.tb00154.x

Boxall, P., \& Purcell, J. (2002). Strategy and human resource management. Basingstoke: Palgrave.

Budhwar, P., \& Debrah, Y.A. (2009). Future research on human resource management systems in Asia. Asia Pacific Journal of Management, 26, 197-218. http://dx.doi.org/10.1007/s10490-0089103-6

Campbell, C.M. (1997). The determinants of dismissals, quits and layoffs: A multinomial logit approach. Southern Economic Journal, 63(4), 1066-1073. http://dx.doi.org/10.2307/1061241

Cavanaugh, M.A., \& Noe, R.A. (1999). Antecedents and consequences of relational components of the new psychological contract. Journal of Organizational Behavior, 20, 323-340. http://dx.doi.org/10.1002/(SICI)1099-1379(199905)20:3<323: :AID-JOB901>3.0.CO;2-M

CIPD. (2008). The psychological contract. London: Chartered Institute of Personnel and Development.

Coyle-Shapiro, J.A-M. (2002). A psychological contract perspective on organizational citizenship behaviour. Journal of Organizational Behavior, 23, 927-946. http://dx.doi.org/10.1002/job.173

Coyle-Shapiro, J.A-M., \& Kessler, I. (2000). Consequences of the psychological contract for the employment relationship: A large-scale survey. Journal of Management Studies, 37(7), 903-930. http://dx.doi.org/10.1111/1467-6486.00210 
Coyle-Shapiro, J.A-M., \& Kessler, I. (2003). The employment relationship in the U.K. public sector: A psychological contract perspective. Journal of Public Administration Research and Theory, 13(2), 213-230. http://dx.doi.org/10.1093/jopart/mug018

Cronbach, L.J. (1951). Coefficient alpha and the internal structure of tests. Psychometrika, 16, 297-334. http://dx.doi.org/10.1007/BF02310555

Cullinane, N., \& Dundon, T. (2006). The Psychological Contract: A Critical Review. International Journal of Management Reviews, 8(2), 113-229. http://dx.doi.org/10.1111/j.14682370.2006.00123.x

Davila, A., \& Elvira, M.M. (2007). Psychological contracts and performance management in Mexico. International Journal of Manpower, 28(5), 384-402. http://dx.doi.org/10.1108/01437720710778385

Delaney, J.T., \& Huselid, M.A. (1996). The impact of human resource management practices on perceptions of organizational performance. Academy of Management Journal, 39, 949-969. http://dx.doi.org/10.2307/256718

DeWitt, R.L. (1998). Firm, industry, and strategy influences of choice of downsizing approach. Strategic Management Journal, 19, 59-80. http://dx.doi.org/10.1002/(SICI)10970266(199801)19:1<59::AID-SMJ934>3.0.CO;2-2

European Economy (2011). Statistical Annex of European Economy. European Commission.

Frankfort-Nachmias, C., \& Nachmias, D. (1996). Research methods in the social sciences. New York: St. Martin's Press.

Gerhart, B., Wrigth, P.M., McMaham, G.C., \& Snell, S.A. (2000). Measurement error in research on human resource $s$ and firm performance: how much error is there and how does it influence effect size estimates? Personnel Psychology, 53, 803-834. http://dx.doi.org/10.1111/j.1744-6570.2000.tb02418.x

Gomez-Mejia, L.R., Balkin, D.B., \& Cardy, R.L. (2004). Managing human resources. Upper Saddle River, NJ: Pearson Education.

Griffith, C. (1998) Building a resilient work force. Training, 35(1), 54-60.

Grimmer, M., \& Oddy, M. (2007). Violations of the psychological contract: The mediating effect of relational versus transactional beliefs. Australian Journal of Management, 31(1), 153-173. http://dx.doi.org/10.1177/031289620703200109

Guest, D., \& Conway, N. (2002). Communicating the Psychological Contract: An Employer Perspective. Human Resource Management Journal, 12(2), 22-38. http://dx.doi.org/10.1111/j.1748-8583.2002.tb00062.x 
Guest, D., \& Conway, N. (2004). Employee well-being and the psychological contract: A report for the CIPD. London: Chartered Institute of Personnel and Development.

Guest, D., Conway, N., Briner, R., \& Dickman, M. (1996). The state of the psychological contract in employment. London: Chartered Institute of Personnel and Development. http://dx.doi.org/10.1111/1467-8543.00273

Guest, D.E., Mitchie, J., Conway, N., \& Sheehan, M. (2003). Human resource management and corporate performance in the UK. British Journal of Industrial Relations, 41(2), 291-314.

Hair, F., Anderson, R., Tatham, R., \& Black, W. (2008). Multivariate data analysis with readings. London: Prentice-Hall.

Harman, H.H. (1967). Modern factor analysis. Chicago, IL: University of Chicago Press.

Heyes, J., \& Stuart, M. (1996). Does training matter? Employee experiences and attitudes. Human Resource management Journal, 6(3), 7-21. http://dx.doi.org/10.1111/j.17488583.1996.tb00409.x

Hutchison, S., \& Purcell, J. (2003). Bringing Policies to Life - The vital role of front line managers in people management. London: CIPD.

de Jong, J., Schalk, R., \& de Cuyper, N. (2009). Balanced versus unbalanced psychological contracts in temporary and permanent employment: Associations with employee attitudes. Management and Organization Review, 5(3), 329-351. http://dx.doi.org/10.1111/j.1740$\underline{8784.2009 .00156 . x}$

Jöreskog, K.G., \& Sörbom, D. (2004). LISREL 8.7 for Windows [Computer Software]. Lincolnwood, IL: Scientific Software International, Inc.

Katou, A.A. (2008). Measuring the impact of HRM on organisational performance. Journal of Industrial Engineering and Management, 1(2), 119-142. http://dx.doi.org/10.3926/jiem.2008.v1n2.p119-142

Lee, S-H., Phan, P., \& Tan, G.Y.W. (2003). Impact of Asian economic crisis on training intensions and outcomes. Human Resource Management Review, 13, 467-486. http://dx.doi.org/10.1016/S1053-4822(03)00046-9

Lemire, L., \& Rouillard, C. (2005). An empirical exploration of the psychological contract violation and individual behavior. Journal of Managerial Psychology, 20, 150-163. http://dx.doi.org/10.1108/02683940510579786

Lester, S.W., Claire, E., \& Kickull, J. (2001). Psychological contracts in the $21^{\text {st }}$ century: What employees values most and how well organizations are responding to these expectations. Human Resource Planning, 24, 10-21. 
Luna-Arocas, R., \& Camps, J. (2008). A model of high performance work practices and turnover intentions. Personnel Review, 37, 26-46. http://dx.doi.org/10.1108/00483480810839950

Luo, Y. (2002). Corruption and organisation in Asian Management Systems. Asia Pacific Journal of Management, 19, 405-422. http://dx.doi.org/10.1023/A:1016252021370

MacNeil, I.R. (1985). Relational contract: What we do and do not know. Wisconsin Law Review, 483-525.

Marchington, M. (2001). Employee involvement at work. In Storey, G. (ed.). Human resource management: A critical text. London: Thomson.

Martin, G., Staines, H., \& Pate, J. (1998). Linking job security and career development in a new psychological contract. Human Resource Management Journal, 8(3), 20-40. http://dx.doi.org/10.1111/j.1748-8583.1998.tb00171.x

McKinley, W., Mone, M.A., \& Barker, V.L. (1998). Some ideological foundations of organizational downsizing. Journal of Management Inquiry, 7(3), 198-212. http://dx.doi.org/10.1177/105649269873002

McDonald, D.J., \& Makin, P.J. (2000). The psychological contract, organizational commitment and job satisfaction of temporary staff. Leadership and Organization Development Journal, 21(2), 84-91. http://dx.doi.org/10.1108/01437730010318174

Millward, L.J., \& Brewerton, P.M. (1999). Contractors and their psychological contracts. British Journal of Management, 10, 253-274. http://dx.doi.org/10.1111/1467-8551.00131

Morrison, E.W., \& Robinson, S.L. (1997). When employees feel betrayed: A model of how psychological contract violation develops. Academy of Management Review, 22(1), 226-256.

Nelson, L., \& Tonks, G. (2007). Violations of the psychological contract: Experiences of a group of causal workers. Research and Practice in Human Resource Management, 15(1), 22-36.

Nunnally, J.C. (1978). Psychometric theory. New York: McGraw-Hill.

Paauwe, J., \& Boselie, P. (2003). Challenging 'strategic HRM' and the relevance of the institutional setting. Human Resource Management Journal, 13(3), 56-70. http://dx.doi.org/10.1111/j.1748-8583.2003.tb00098.x

Paauwe, J., \& Boselie, P. (2005). HRM and performance: What's next? Human Resource Management Journal, 15(4), 68-83. http://dx.doi.org/10.1111/j.1748-8583.2005.tb00296.x

Paauwe, J., \& Richardson, R. (1997). Introduction: Special issue on HRM and performance. International Journal of Human Resource Management, 8(3), 257-262. http://dx.doi.org/10.1080/095851997341621 
Pate, J., Martin, G., \& McGoldrick, J. (2003). The impact of psychological contract violation on employee attitudes and behaviour. Employee Relations, 25, 557-573. http://dx.doi.org/10.1108/01425450310501306

Pavlou, P.A., \& Gefen, D. (2005). Psychological contract violation in online marketplaces: Antecedents, consequences, and moderating role. Information Systems Research, 16(4), 372-399. http://dx.doi.org/10.1287/isre.1050.0065

Pedhazur, E.J., \& Pedhazur-Schmelkin, L. (1991). Measurement, design, and analysis: An integrated approach. Hillsdale, NJ: Lawrence Erlbaum.

Podsakoff, P.M., \& Organ, D. (1986). Self-reports in organization research: problems and prospects. Journal of Management, 12, 531-544. http://dx.doi.org/10.1177/014920638601200408

Purcell, J., \& Hutchinson, S. (2007). Front-line managers as agents in the HRM-performance causal chain: theory, analysis and evidence. Human Resource Management Journal, 17(1), 3-20. http://dx.doi.org/10.1111/j.1748-8583.2007.00022.x

Purcell, J., Kinnie, N., \& Hutchinson, S. (2003). Understanding the people and performance link: Unlocking the black box. London: Chartered Institute of Personnel Development.

Robinson, S.L. (1996). Trust and breach of the psychological contract. Administrative Science Quarterly, 41(4), 574-400. http://dx.doi.org/10.2307/2393868

Robinson, S.L., Kraatz, M.S., \& Rousseau, D.M. (1994). Changing obligations and the psychological contract: A longitudinal study. Academy of Management Journal, 37(1), 137-152. http://dx.doi.org/10.2307/256773

Robinson, S.L., \& Rousseau, D.M. (1994). Violating the psychological contract: Not the exception but the norm. Journal of Organizational Behavior, 15, 245-259. http://dx.doi.org/10.1002/job.4030150306

Rousseau, D.M. (1990). New hire perceptions of their own and their employer's obligations: A study of psychological contracts. Journal of Organizational Behavior, 11, 389-400. http://dx.doi.org/10.1002/job.4030110506

Rousseau, D.M. (1995). Psychological contracts in organizations understanding the written and unwritten agreements. London: Sage. http://dx.doi.org/10.1016/S0090-2616(99)90026-8

Rousseau, D.M., \& Arthur, M.B. (1999). The boundary less human resource management: Building agency and community in the new economic era. Organizational Dynamics, 27(4), 6-18. 
Rousseau, D.M., \& McLean Parks, J. (1993). The contracts of individuals and organizations. In Cummings, L.L., \& Staw, B.M. (eds.). Research in organizational behaviour. Greenwich, Conn.: JAI Press.

Rynes, S.L. (1991). Recruitment, job choice, and post-hire consequences: A call for new research directions. In Dunnette, M.D., \& Hough, L.M. (eds.) Handbook of industrial and organizational psychology. Palo Alto, CA: Consulting Psychologists Press.

Seeck, H., \& Parzefall, M.-R. (2010). From HRM to psychological contracting - the case of Finnish mobile content producing companies. The International Journal of Human Resource Management, 21(15), 2677-2693. http://dx.doi.org/10.1080/09585192.2010.528650

Straub, D. (1989). Validating instruments in MIS research. MIS Quarterly, 13(2), 147-169. http://dx.doi.org/10.2307/248922

Sturges, J., Conway, N., Guest, D., \& Liefooghe, A. (2005). Managing the career deal: The psychological contract as a framework for understanding career management, organizational commitment and work behaviour. Journal of Organizational Behavior, 26(7), 812-838. http://dx.doi.org/10.1002/job.341

Suazo, M.M., Martinez, P.G., \& Sandoval, R. (2009). Creating psychological and legal contracts through human resource practices: A signalling theory perspective. Human Resource Management Review, 19, 154-166. http://dx.doi.org/10.1016/j.hrmr.2008.11.002

Sutton, G., \& Griffin, M. (2004). Integrating expectations, experiences and psychological contract violations: A longitudinal study of new professionals. Journal of Occupational and Organizational Psychology, 77, 493-514. http://dx.doi.org/10.1348/0963179042596487

Taylor, M.S., \& Tekleab, A.G. (2004). Taking stock of psychological contract research: Assessing progress, addressing troublesome issues, and setting research priorities. In Coyle-Shapiro, J.A.-M. Shore, L.M., Taylor, M.S., \& Tetrick, L.E. (eds.). The employment relationship: Examining contextual and psychological perspectives. Oxford: Oxford Univesrity Press.

Tekleab, A.G., Lepak, D., \& Bartol, K.M. (2001). Psychological Contracts: A Mediator Between HRM Practices and Employee Attitude Relationship. Paper presented at the Society for Industrial Organizational Psychology National Meeting, San Diego, CA.

Turnley, W.H., \& Feldman, D.C. (2000). Re-examining the effects of psychological contract violations: Unmet expectations and job dissatisfaction as mediators. Journal of Organizational Behavior, 21(1), 25-42. http://dx.doi.org/10.1002/(SICI)1099-1379(200002)21:1<25: :AIDJOB2>3.0.CO;2-Z 
Tzafrir, S.S. (2005). The Relationship between trust, HRM practices and firm performance. International Journal of Human Resource Management, 16, 1600-1622. http://dx.doi.org/10.1080/09585190500239135

Westwood, R., Sparrow, P., \& Leung, A. (2001). Challenges to the psychological contract in Hong Kong. International Journal of Human Resource Management, 12(4), 621-651.

Wright, P.M., \& Boswell, W.R. (2002). Desegregating HRM: a review and synthesis of micro and macro human resource management research. Journal of Management, 28(3), 247-276. http://dx.doi.org/10.1177/014920630202800302

Wright, P.M., \& Gardner, T.M. (2003). Theoretical and empirical challenges in studying the HR practice - firm performance relationship. In Holman, D., Wall, T.D., Clegg, C., Sparrow P., \& Howard, H. (eds.). The new workplace: people technology, and organization. Sussex: John Wiley and Sons.

Wright, P.M., Gardner, T.M., \& Moynihan, L.M. (2003). The impact of HR practices on the performance of business units. Human Resource Management Journal, 13(3), 21-36. http://dx.doi.org/10.1111/j.1748-8583.2003.tb00096.x

Wright, P.M., Gardner, T.M., Moynihan, L.M., \& Allen, M.R. (2005). The relationship between HR practices and firm performance: Examining causal order. Personnel Psychology, 58, 409-446. http://dx.doi.org/10.1111/j.1744-6570.2005.00487.x

Zhao, H., Wayne, S.J., Glibkowski, B.C., \& Bravo, J. (2007). The impact of psychological contract breach on work-related outcomes: A meta-analysis. Personnel Psychology, 60, 647-680. http://dx.doi.org/10.1111/j.1744-6570.2007.00087.x

Journal of Industrial Engineering and Management, 2013 (www.jiem.org)

Article's contents are provided on a Attribution-Non Commercial 3.0 Creative commons license. Readers are allowed to copy, distribute and communicate article's contents, provided the author's and Journal of Industrial Engineering and Management's names are included. It must not be used for commercial purposes. To see the complete license contents, please visit http://creativecommons.org/licenses/by-nc/3.0/. 